\title{
Mediator effect of Brand Image on the relationship between Service Quality and Patient Loyalty in the Out Patients Department of the Lady Ridgeway Hospital for Children, Colombo.
}

Wickremasinghe WK, Chandrika GHTNK.

\begin{abstract}
Introduction: The utilization pattern of public hospitals in Sri Lanka is different, some are underutilized and some are over utilized. The Lady Ridgeway Hospital for Children gets its clients from all corners of the country. As it is known in the competitive health care industry, the impact of perceived quality of care on the attitudes and behavior of visit and re-visit intention of the customers towards hospitals is becoming an important issue.
\end{abstract}

Objective: To examine the relationship between perceived quality of care and client loyalty, to ascertain whether there is a Brand Equity towards the Lady Ridgeway Hospital among its customers and how the Brand Equity affects the association of perceived quality towards patients loyalty.

Methodology: For the purpose of the study data was collected from 371 respondents who sought outpatient care from the Lady Ridgeway Hospital for Children Colombo.

Results: The study revealed that customers from all social layers seek care at the Lady Ridgeway Hospital. Results also revealed that perceive quality of care has positive effect on the patient loyalty towards hospital and hospital has a good Brand Image and it plays a mediating role in this association. Patient Loyalty mainly depends on the qualitative aspects of the services provided and not on the socio-economic factors of the patients. Results imply that perceived quality of care received by the patients lead to build up of Brand Equity towards the hospital which in turn leads to patient loyalty towards Lady Ridgeway Hospital for Children, Colombo.

\section{Introduction}

Lady Ridgeway Hospital (LRH) for Children is the premier Tertiary Care Teaching Hospital for children in Sri Lanka, situated in Colombo, Sri Lanka, was established in 1896. LRH with 973 beds renders its services for children less than 14 years of age. It provides inward services for almost all clinical specialties. The Out Patient Department (OPD) serves to an average of 1500 to 2000 patients daily. LRH OPD gets patients from all over the country who come by their own will, without any kind of referral. At a glance one can see overcrowding of the OPD, especially during epidemics such as Dengue. This led researchers to think LRH has its own brand name that has augmenting effects towards patients to seek care in the hospital and service quality of the hospital which makes patients loyal towards the hospital.

\section{Objective}

To examine the relationship between perceived quality of care and client loyalty, to ascertain whether there is a Brand Equity towards the Lady Ridgeway Hospital among its customers and how the Brand Equity affects the association of perceived quality towards patient loyalty.

\section{Methodology}

Study was carried out as a prospective descriptive study at the Out Patients Department of the Lady Ridgeway Hospital for Children, Colombo from June 2018 to September 2018 and, at the end 371 respondents out of planned 384 were interviewed.

Patients seeking care at the OPD of the LRH randomly selected were included in the study. Due to the nature of patients being children their mother, father or guardian who accompanied the child, was interviewed. The study was conducted using an interviewer administered questionnaire, which consisted of two main parts. The first part of the questionnaire was on Socio-Demographic data, and the second included questions to secure data on independent (service quality), dependent (loyalty) and mediator variables (brand image). Measurement on each question was done using 1-5 scale where 5 was given to 'strongly agree' response and 1 point was allocated to 'strongly disagree' response. The second part of the questionnaire was developed on the basis of SERVQUAL: multiple-item scale for measuring consumer perception of service quality, modified to suit the needs of the research.

\section{Results}

According to the study findings mean age of customers was 31.67 years, $43.9 \%$ of the respondents belong to the $31-40$ age range and $29.1 \%$ were in $21-30$ years age group. Ninety percent were females, accompanying their sick children. Of them $64.2 \%$ were Sinhalese, $18.3 \%$ were Tamils and $16.7 \%$ were Muslims. Fifty eight and half percent of the respondents were Buddhists, $12.9 \%$ were Christians, $17.5 \%$ were Muslims and $11.1 \%$ were 
Hindus. The distribution of the sample population however was not reflecting the national proportions for ethnicity and religion. Sixty-four-point seven percent had O/L or A/L education and $24.5 \%$ of the population had an education below 11th grade. Only $3 \%$ of the population had higher educational qualifications. In keeping with the education level of the general population, a great majority of the respondents had adequate education that in return may have had higher expectations. Details of average monthly income of the respondents showed that client of the hospital belong to all social levels of the society. Only one person had indicated that their monthly income is less than 10,000 rupees. About $9 \%$ of those had 10,000 to 20,000 monthly income while about $32 \%$ had indicated that their monthly income was ranging from 20,000 to 30,000 , while $29.4 \%$ had indicated that their monthly income was more than 45,000 rupees.

\subsection{Descriptive statistics}

Perceived quality was the independent variable of the study. Assessment of perceived quality domain was done by the five operationalized variables, namely tangibility, reliability responsiveness, assurance and empathy. The overall mean value for perceived quality of healthcare domain was equal to 3.81 which means majority of customers agreed that quality of care provided by the hospital is good. Customer loyalty, the dependent variable in the study was assessed by five separate items. The great majority agreed that they selected this institution as their first choice, that they visit this institution generally for treatment and they also recommend this institution to friends and relatives. The overall mean value of 4.11 shows that loyalty to Lady Ridgeway Hospital is high among its customers. Brand equity, the mediator variable was assessed in sub domains such as brand awareness, brand attitude, brand prestige, brand trust $\&$ brand commitment. The overall mean value for brand equity being 4.82 , once again confirms the high brand equity towards the hospital among its clients.

\subsection{Reliability Test}

A well-known approach to measure reliability is to use the Cronbach alpha. The value of Cronbach alpha with the range of greater than 0.70 is considered acceptable and good (Cavana et al., 2001). Results from the Table 1 show that Cronbach alpha for the seven constructs were well above 0.70 out of 10 . Based on the finding, Cronbach alpha for the construct ranged from lowest of 0.57 (Responsiveness) to 0.96 (brand attitude). In conclusion, the outcome concluded that the measurement scales of the constructs were stable and consistent in measuring the constructs.

Table 1: Reliability of the Constructs

\begin{tabular}{|c|c|c|c|c|c|}
\hline \multirow[t]{2}{*}{ Constructs } & & \multicolumn{4}{|c|}{ Composite Reliability } \\
\hline & & Alpha & Items & Alpha & Items \\
\hline Perceived quality & & & & 0.28 & 5 \\
\hline Tangibles & - & 0.67 & 7 & & \\
\hline Reliability & - & 0.76 & 3 & & \\
\hline Responsiveness & - & 0.57 & 5 & & \\
\hline Assurance & - & 0.70 & 3 & & \\
\hline Empathy & - & 0.78 & 4 & & \\
\hline Customer loyalty & - & & & 0.34 & 5 \\
\hline Brand equity & & & & 0.81 & 6 \\
\hline Brand equity & - & 0.93 & 2 & & \\
\hline Brand awareness & & 0.61 & 5 & & \\
\hline Brand attitude & - & 0.96 & 2 & & \\
\hline Brand prestige & - & - & 1 & & \\
\hline Brand trust & - & 0.93 & 4 & & \\
\hline Brand commitment & - & 0.82 & 2 & & \\
\hline
\end{tabular}

\subsection{Correlation among variables}

Table 2 shows that correlation matrix contained most of correlations above 0.40 and most of the correlations are significant at $\mathrm{p}<0.05$ and $\mathrm{p}<0.01$ level. Furthermore, each of the components also well correlated $(0.40$ and above $)$ with the overall measure of perceived quality. 


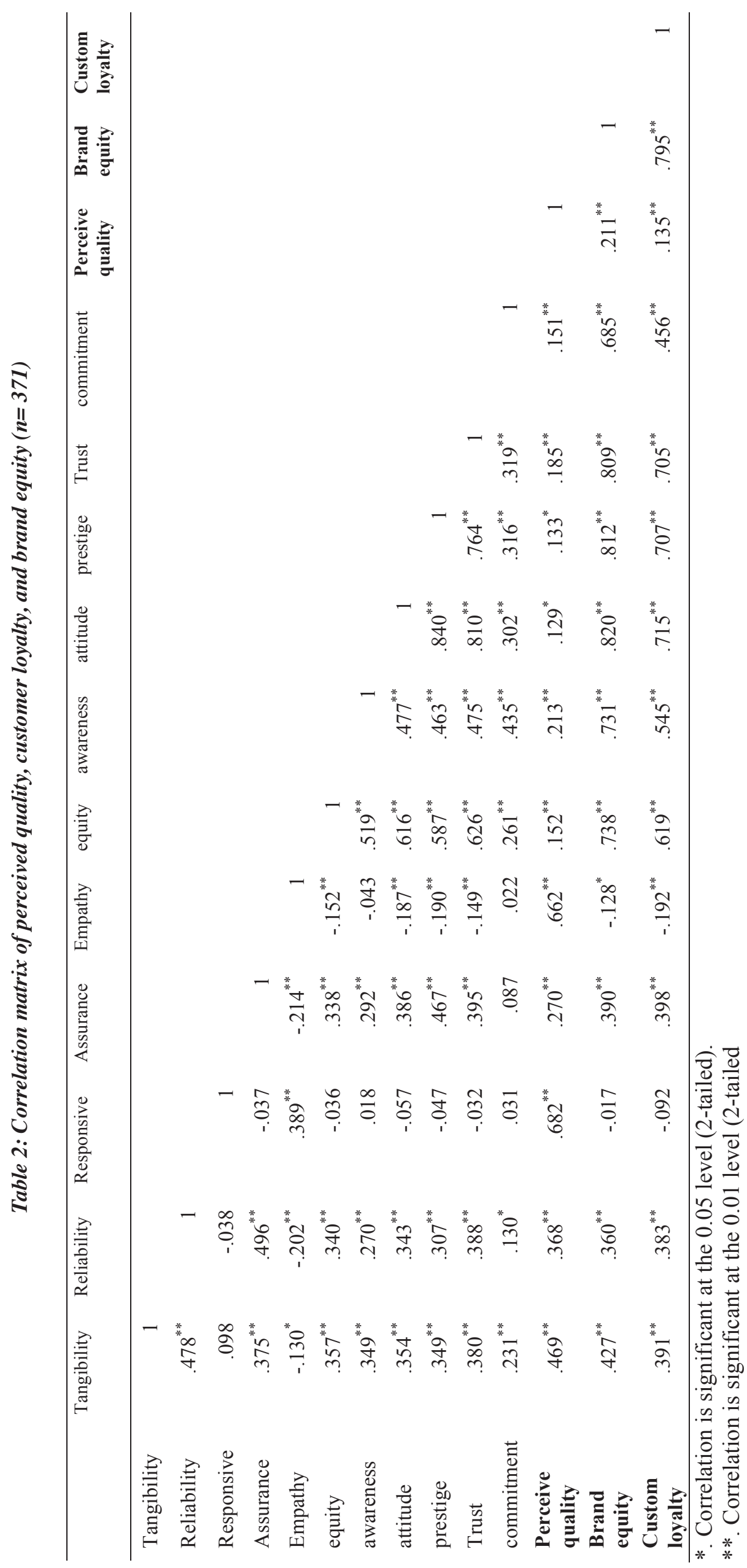




\subsection{Results of multivariate analysis}

4.4.1 Service quality positively influences brand equity - Hypothesis 1(H1)

Table 3: Summary of regression results $(n=371)$

\begin{tabular}{llrrrrr}
\hline Dependent var. & Independent var. & $\mathbf{R}(\mathbf{R} 2)$ & $\boldsymbol{\beta}$ - Beta & T-value & T-sig. & F-value, sig. \\
\hline Brand equity & Perceived quality & $\mathbf{0 . 2 1}(\mathbf{0 . 0 5})$ & $\mathbf{0 . 2 3 1}$ & $\mathbf{4 . 1 5}$ & $<\mathbf{0 . 0 0 1}$ & $\mathbf{1 7 . 2 1 , < 0 . 0 0 1}$ \\
\hline & & 0.204 & 5.538 & 0.000 & \\
& Tangibles & & 0.083 & 1.887 & 0.060 & \\
& Reliability & & -0.016 & -0.603 & 0.547 & $\mathbf{2 4 . 7 0 , < 0 . 0 0 1}$ \\
& Responsiveness & $\mathbf{0 . 5 0 ( 0 . 2 5 )}$ & 0.300 & 4.202 & 0.000 & \\
& Assurance & & -0.003 & -0.174 & 0.862 & \\
& Empathy & & & & \\
\hline
\end{tabular}

To examine the effect of service quality on brand equity, regression analysis has been conducted. The hypothesis-1 (H1) tests as shown in Table 3, the H1: hypothesized relationship is supported in the estimated structural model. As shown in table, Perceived quality has significant positive effects on brand equity $(\beta=0.231$, $\mathrm{t}$-value $=4.149)$. Hence, $\mathrm{H} 1$ is supported.

4.4.2 Brand equity positively influences patient loyalty - Hypothesis 2 (H2)

Testing of hypothesis $2(\mathrm{H} 2)$ is shown in Table 4. Hypothesized relationship is significant in the estimated structural model. As shown in table, brand equity has significant positive effects on patient loyalty $(\beta=0.903$, $\mathrm{t}$-value $=$ 25.203). Hence, $\mathrm{H} 2$ is supported.

Table 4: Summary of regression results $(n=371)$

\begin{tabular}{llrrrrr}
\hline Dependent var. & Independent var. & $\mathbf{R}(\mathbf{R})$ & $\boldsymbol{\beta}$ - Beta & t-value & T-sig. & F-value, sig. \\
\hline Patient loyalty & Brand equity & $\mathbf{0 . 7 9 5}(\mathbf{0 . 6 3 3})$ & $\mathbf{0 . 9 0 3}$ & $\mathbf{2 5 . 2 0}$ & $<\mathbf{0 . 0 0 1}$ & $\mathbf{6 3 5 , 2 0 , < \mathbf { 0 . 0 0 1 }}$ \\
\hline & & 0.158 & 3.856 & $<0.000$ & \\
& Equity & & 0.098 & 2.721 & 0.007 & \\
& Awareness & & 0.188 & 2.791 & 0.006 & $114.12,<0.001$ \\
& Attitude & $0.808(0.653)$ & 0.194 & 3.464 & 0.001 & \\
& Prestige & & 0.212 & 3.270 & 0.001 & \\
& Trust & 0.095 & 5.368 & $<0.000$ & \\
& Commitment & & & & \\
\hline
\end{tabular}

4.4.3 Relationships among Brand equity, perceived quality and customer loyalty Hypothesis 3(H3)

Table 5: Summary of regression results $(n=371)$

\begin{tabular}{|c|c|c|c|}
\hline \multirow[t]{2}{*}{ Independent Variable } & Brand equity (Mediator) & \multicolumn{2}{|c|}{ Patient loyalty (Dependent Variable) } \\
\hline & Model 1 & Model 2 & Model 3 \\
\hline \multirow{2}{*}{ Perceived quality } & $0.2307^{*}$ & $0.1682 * *$ & $0.0421(\mathrm{NS})$ \\
\hline & 1st equation & 2nd equation & 3rd equation \\
\hline \multirow[t]{2}{*}{ Brand equity } & & & $0.9114 *$ \\
\hline & & & 3rd equation \\
\hline
\end{tabular}

$* p<0.00, * * p=0.009$, NS $=$ Not Significant $(p=0.2396, p>0.05)$

According to the finding from Table above, perceived quality as an independent variable significantly affects the brand equity as a mediator in equation; perceived quality as an independent variable significantly affects the patient loyalty as a dependent variable in equation two; both perceived quality as an independent variable and brand equity as a mediator considerably impacted the patient loyalty as a dependent variable. Hypothesis 3 (H3) is supported 
because the beta value of perceived quality in equation three $(\mathrm{beta}=0.0421)$ is smaller than the beta value of perceived quality in equation two (beta $=0.1682)$, diminishing by $0.1260(0.1682-0.0421)$. In conclusion, brand equity does act as a mediator in mediating the relationship between perceived quality and customer loyalty.

A Sobel test was conducted and found full mediation in the model $(z=4.09, p<0.000)$. It was also found that brand equity is mediated the relationship between perceived quality of care and loyalty intention to the customer.

Table 6: Conclusion of the hypotheses in the study.

\begin{tabular}{lll}
\hline Hypothesis & Relationship & Conclusion \\
\hline H1 & Perceived quality $\rightarrow$ brand equity & Supported \\
H2 & Brand equity $\rightarrow$ patient loyalty & Supported \\
H3 & $\begin{array}{l}\text { Service quality } \rightarrow \text { has a positive influence and, indirect effect on patient } \\
\text { loyalty mediated by brand equity. }\end{array}$ & Supported \\
\hline
\end{tabular}

\section{Discussion}

The study was conducted to investigate the effect of perceived quality of care on customer loyalty at OPD, LRH and also whether there is effect of brand equity which mediates customer loyalty towards Lady Ridgeway Hospital. Extensive literature search did not reveal any published similar studies done in Sri Lanka. Therefore, most of the literature support and explanations were based on the studies conducted in other parts of the world.

Perceived quality of care is well known standard attribute used all over the world to assess the quality of care given to the customers at the healthcare institutions. In overall perceived quality of care in the Lady Ridgeway Hospital found to be good since majority with mean value of 3.81 agreed to it.

Customer loyalty is the result of consistently positive emotional experience, physical attribute-based satisfaction and perceived value of an experience, which includes the product or services. Overall mean value close to 4 is the confirmation of the loyalty of customers towards Lady Ridgeway Hospital.

Brand equity refers to the value of a brand. A strong brand name works as a credible signal of product quality for imperfectly informed customers. When customers are satisfied by getting desired values from organizations, customers may in return provide value to organizations. Brand equity in healthcare is built through the continuous accumulation of thoughts, feelings, opinions, and behaviors regarding a hospital or health system based on the experience it provides the customer. The overall mean value of 4.82 confirms it towards LRH.

The outcome of reliability test concluded that the measurement scales of the constructs were stable and consistent in measuring the constructs. Most of the correlations are significant and each of the components also well correlated with the overall measure of perceived quality. The results of multivariate analysis concluded that all three hypotheses are well supported.

\section{Conclusions}

The study revealed that perceived quality as an independent variable significantly affect the brand equity as a mediator and perceived quality as an independent variable significantly affect the customer loyalty as a dependent variable. And both perceived quality as an independent variable and brand equity as a mediator considerably impacted the customer loyalty as a dependent variable. Therefore, study concluded that brand equity does act as a positive mediator between perceived quality and customer loyalty that patient's loyalty greatly influenced by the perceived quality of care by the patients and brand equity play significant positive effect on patient's loyalty towards Lady Ridgeway Hospital, Colombo. 


\section{References}

1. Aaker David A. (1996). Brand Portfolio strategy. Free Press, New York, p. 380.

2. Alure Gowda. (2013). Role of Brand Awareness in Health Care Industry. International Monthly Refereed Journal of Research In Management \& Technology, Vol. II

3. Alwi, S.F.S. (2009). Online Corporate Brand Images and Consumer Loyalty, International Journal of Business \& Society, Vol. 10, no. 2, pp. 1-19.

4. amednews.com. (2006). What makes patients loyal? It may take more than you think. [online] American medical association. Available at: http://www.amednews.com/ article/ 20061204/ business/312049995/4/ [Accessed 28th Feb 2018].

5. Berkawitz, E. N. \& Flexner, W.A. (1980-81). The Market for Health Care Services: Is There A Non Traditional Consumer?, Journal of Health Care Marketing, 1(1), pp. 25-34.

6. Bhanu Prakash.(2010). Patient Satisfaction. Journal of Cutaneous and Aesthetic Surgery Sep-Dec; 3 (3).

7. Buttle, F. and Burton, J. (2002). Does service failure influence customer loyalty? Journal of Consumer Behaviour, Vol. 1, 3, pp.217-227.

8. Cavana, R. Y., Delahaye, B. L., \& Sekaran, U. (2001). Applied business research: Qualitative and quantitative methods. Queensland: John Wiley \& Sons.

9. Donohue, Ryan. (2016) Brand Equity in Healthcare: The Impact of Branding in a Changing Healthcare Landscape, [On line] National Research Corporation Available at: https://nrchealth.com/ wp-content/uploads/2016/10/Brand-Equity-CaseStudy.pdf [Accessed 27th Feb 2018]

10. East, R., Hammond, K., Lomax, W., Robinson, H. (2005). "What is the Effect of a Recommendation?" Marketing Review, Vol. 5, no. 2, pp. 145-157.

11. Heung, V.C.S., Mok, C. \& Kwan, A. (1996). Brand Loyalty in Hotels: An Exploratory Study of Overseas Visitors to Hong Kong, Australian Journal of Hospitality Management, 3(1), pp. 1-11.
12. Lady Ridgeway Hospital for Children, Annual Report, Colombo, 2016

13. Park, C. and Srinivasan, V. (1994). A survey-based method for measuring and understanding brand equity and its extendibility, Journal of Marketing Research, vol. 31 No. 2, May, pp. 271-88.

14. Philip Kotler, Gary Armstrong.(2012).Principles of marketing. Prentice Hall, One Lake Street, Upper Saddle River, New Jersey 07458.

15. Rishi Sikka, Tina Esposito, Jim Skogsbergh. (2016). Why Patient Loyalty Matters in Health Care,[online] Hospital \& Health networks. Available at: http:// www.hhnmag.com/ articles/7432-why-patientloyalty-matters-in-health-care [Accessed 28th Feb 2018].

16. Rothberg, M.B., Morsi, E., Benjamin, E.M., et al. (2008). Choosing the best hospital: the limitations of public quality reporting. Health Affairs, pp. 1680-1687.

17. Sener, H. Y. (2014). Improving Patient Satisfaction in Health Services: An Application at Dumlupinar University Kutahya Evliya Celebi Education \& Research Hospital. European Journal of Business Management. pp. 172-181.

18. Woodside, A.G., Frey, L.L. \& Daly, R. T. (1989). Linking Service Quality, Customer Satisfaction, and Behavioral Intention. Journal of Health Care Marketing. pp. 5-17.

19. World Health Organization. (2015). World Health Report. WHO, Geneva.

20. Zeithaml, V. A., Parasuraman, A., Berry, L. L. (1990). Delivering Quality Service: Balancing Customer Perceptions and Expectations. New York, The Free Press. 
ISSN: 1391-2909

Printed by Lazergraphic (Pvt) Ltd 